\title{
PHASE SEPARATION LIQUID-LIQUID EXTRACTION FOR THE QUANTIFICATION OF 8-ISO-PROSTAGLANDIN F2 ALPHA IN HUMAN PLASMA BY LC-MS/MS
}

\author{
FAZNO DELJENJE EKSTRAKCIJE TEČNO - TEČNO ZA KVANTIFIKACIJU \\ 8-IZO-PROSTAGLANDINA F2 $\alpha$ U LUUDSKOJ PLAZMI POMOĆU LC-MS/MS METODE
}

\author{
Desislav Tomov1,5, Georgeta Bocheva2, Vidka Divarova1,3, \\ Lilia Kasabova ${ }^{4}$, Dobrin Svinarov ${ }^{4}$ \\ ${ }^{1}$ Technological Center for Emergency Medicine, Plovdiv, Bulgaria \\ ${ }^{2}$ Department of Pharmacology and Toxicology, Faculty of Medicine, Medical University of Sofia, Sofia, Bulgaria \\ ${ }^{3}$ Department of Chemical Sciences, Faculty of Pharmacy, Medical University of Plovdiv, Plovdiv, Bulgaria \\ ${ }^{4}$ Clinical Laboratory \& Clinical Pharmacology, UMBAL Alexandrovska, Faculty of Medicine, \\ Medical University of Sofia, Sofia, Bulgaria \\ ${ }^{5}$ Department of Bioorganic Chemistry, Faculty of Pharmacy, Medical University of Plovdiv, Plovdiv, Bulgaria
}

\begin{abstract}
Summary
Background: Reactive oxygen species (ROS) are produced in the body during normal metabolism by means of enzymes and non-enzymatic chemical reduction of molecular oxygen. In case of the prevalence of ROS formation over their elimination, highly reactive free radicals can be accumulated and can cause multiple damages to the biomolecules and cells. Determination of isoprostanes in biological matrices is most often used to register free radical damage and requires selective, sensitive and specific techniques.

Methods: This study presents the development and validation of the LC-MS/MS method for the determination of 8iso-Prostaglandin F2 $\alpha$ in human plasma utilising a modified liquid-liquid extraction procedure with phase separation.

Results: Modified sample preparation procedure assured higher extraction yield, clear separation of organic layer from the plasma water phase and protein precipitates, and better-purified product for instrumental analysis. Linearity was validated in the range $0.1-5.0 \mu \mathrm{g} / \mathrm{L}$ with $\mathrm{R} 2>0.996$; normalised matrix varied between $86.0 \%$ and $108.3 \%$, accuracy ranged from $90.4 \%$ to $113.9 \%$ and precision both within runs and between runs was less than $7 \%$. With a run time of $10 \mathrm{~min}$, a throughput of over 50 samples per working day could be performed.
\end{abstract}

\section{Kratak sadržaj}

Uvod: Reaktivne vrste kiseonika (ROS) nastaju u telu tokom normalnog metabolizma pomoću enzima i neenzimske hemijske redukcije molekularnog kiseonika. U slučaju bržeg formiranja ROS od njihovog eliminisanja, mogu se akumulirati visoko reaktivni slobodni radikali i mogu izazvati višestruka oštećenja biomolekula i ćelija. Određivanje izoprostana u biološkim matricama najčešće se koristi za registrovanje oštećenja prouzrokovana slobodnim radikalima i zahteva selektivne, osetljive i posebne metode rada.

Metode: Ovo istraživanje prikazuje razvoj i validaciju LCMS/MS metode za određivanje 8-izo-prostaglandina F2 $\alpha \mathrm{u}$ ljudskoj plazmi pomoću modifikovanog postupka ekstrakcije tečno-tečno sa razdvajanjem faza.

Rezultati: Modifikovana procedura pripreme uzoraka osigurala je veći učinak ekstrakcije, jasno odvajanje organskog sloja od vodene faze u plazmi i taloga proteina, i bolje pročišćen proizvod za instrumentalnu analizu. Linearnost je potvrđena u opsegu 0,1-5,0 $\mu \mathrm{g} / \mathrm{L}$ sa R2 > 0,996; normalizovana matrica varirala je između 86,0 i 108,3\%, tačnost je bila u rasponu od $90,4 \%$ i $113,9 \%$, a preciznost i u toku i između faza bila je manja od $7 \%$. U toku radnog dana može se izvršiti propusnost od preko 50 uzoraka sa trajanjem od 10 minuta.

\footnotetext{
$\overline{\text { Address for }}$ correspondence:

Desislav G. Tomov

77 Nikola Vaptsarov blvd., Plovdiv, Bulgaria

Phone: +359886097037

e-mail: desislavtomov@gmail.com
}

List of abbreviations: CC, calibration curve; GC, gas chromatography; HPLC, LC, liquid chromatography; IS, internal standard; $\mathrm{MeOH}$, methanol; OS, oxidative stress; $\mathrm{QC}$, quality control; ROS, reactive oxygen species; SRM, selected reaction monitoring. 
Conclusions: The method meets all the current industrial validation criteria and allows the accurate and precise determination of 8-iso-PGF $2 \alpha$ in human plasma at diagnostically significant concentration range.

Keywords: 8-iso-Prostaglandin F2 $\alpha$, liquid extraction with phase separation, LC-MS/MS.

\section{Introduction}

Reactive oxygen species (ROS) are produced in the body during normal metabolism both by means of enzymes and non-enzymatic chemical reduction of molecular oxygen $\left(\mathrm{O}_{2}\right)$. In case of the prevalence of ROS formation over their elimination, highly reactive free radicals can be accumulated and can alter cell functions by causing multiple damages to the biomolecules, including proteins, DNA and lipids, such as polyunsaturated fatty acids (PUFAs) (1-3). The imbalance caused by increased free radicals accumulation and/or decreased antioxidant defence is considered as oxidative stress (OS). ROS are short-lived and are difficult to assess both in vitro and in vivo. Thus, measurement of more stable oxidation products left by ROS in biological fluids and tissues is a well-accepted and widely-applied method for the quantification of OS in vivo (4-6). The particular reaction of ROS with lipids is known as »lipid peroxidation, "which is one of the major mechanisms leading to cellular damage and ultimately to cell death $(1,7-$ 9). The prominent products generated by lipid peroxidation are malondialdehyde and oxidised arachidonic acid derivatives, like $F_{2}$ isoprostanes $(10,11)$ and $15(\mathrm{~S})-8$-iso-PGF $2 \alpha$ in particular, which belong to the most studied OS biomarkers (12-14).

Unlike other lipid peroxidation products (e.g. lipoperoxides and aldehydes), isoprostanes are less reactive and relatively stable $(4,15)$. Isoprostanes can be found in almost all biological fluids including blood plasma, urine (16) and cerebrospinal fluid (17), and their concentration in the tissues, in specific body fluids, or in condensate from exhaled air $(18,19)$, can provide information about OS in a particular organ or system (20). Endogenous isoprostanes are found at low concentrations in biological matrices (21) and either the methods for simultaneous determination of several of them or methods for the measurement of single isoprostanes are employed for the assessment of OS. The major single isoprostane is 15(S)-8-iso$\mathrm{PGF}_{2 \alpha}$, and its quantification is considered as one of the most reliable approaches for the assessment of ROS damage (12-14). The determination of isoprostanes in biological matrices requires selective, sensitive and specific techniques, and despite the variety of published methods, there are still unresolved analytical challenges. The major difficulties are related to their oxidation or their artificial ex vivo formation (22), as well as their low quantities in the samples.
Zaključak: Ova metoda ispunjava sve trenutne kriterijume industrijske validacije $\mathrm{i}$ omogućava tačno $\mathrm{i}$ precizno određivanje 8-izo-PGF2 $\alpha$ u ljudskoj plazmi u dijagnostički značajnom rasponu koncentracije.

Ključne reči: 8-izo-prostaglandin F2 $\alpha$, ekstrakcija tečnosti sa odvajanjem faza, LC-MS/MS

The quantification of isoprostanes employs radio immune assays (RIA), enzyme-linked immune-sorbent assays (ELISA), gas chromatography (GC), high-performance liquid chromatography (HPLC, LC) and capillary electrophoresis with conventional (UV, fluorescence) and mass spectrometric detection. These techniques were recently reviewed by Thakare et al. (23). All of them have advantages, disadvantages, and limitations (16, 21, 24, 25): lack of sufficient selectivity and specificity (ELISA and RIA), extensive sample preparation and chemical derivatisation (GC) etc. Liquid chromatography with tandem mass spectrometry (LC-MS/MS) is the preferred technique for eicosanoid detection in the last 10-15 years, since it provides improved specificity and selectivity, ultimate sensitivity, and much easier sample pre-treatment, compared to GC (26-29). Efficient sample preparation is a critical first step of all separation methods used for the quantification of isoprostanes in biological matrices.

Sample pre-treatment procedures include protein precipitation, liquid-liquid extraction (LLE) and solid-phase extraction with numerous modification steps aiming to increase extraction recovery and decrease matrix effect, such as liquid phase microextraction, single drop micro-extraction, dispersive liquid-liquid micro-extraction, supported liquid membranes, electro membrane extraction, supported liquid extraction, and others (4). Despite the plethora of methods and sample preparation approaches employed for analysis of isoprostanes, certain advantages and disadvantages, common analytical challenges and unresolved problems still remain to be addressed.

The aim of this study was to develop and validate sensitive and selective determination of 15(S)-8iso-PGF ${ }_{2 \alpha}$ in human plasma by LC-MS/MS, utilising classic LLE, improved by phase separation.

\section{Material and Methods}

\section{Chemicals and reagents}

The standards of 8-iso-PGF $2 \alpha$ and its deuterated analogue (8-iso- $\mathrm{PGF}_{2 \alpha}-\mathrm{d} 4$ ) were purchased from Cayman Chemicals (Ann Arbor, MI, USA); LC-MSgrade methanol $(\mathrm{MeOH})$ was delivered by VWR Chemicals BDH (Avantor, USA); 98\% formic acid, ethyl ethanoate, hexane, methylene chloride, and 
sodium phosphate monobasic were obtained from Sigma-Aldrich (St. Louis, MI, USA). Stock solutions of 8-iso-PGF $2 \alpha$ (1.0 mg/L), of 8-iso-PGF $2 \alpha$-d4 (1.0 $\mathrm{mg} / \mathrm{L})$ and working internal standard solution of 8iso-PGF $2 \alpha-d 4(10 \mu \mathrm{g} / \mathrm{L})$ were prepared in $50 \%$ $\mathrm{MeOH}$. From separately prepared stocks, working solutions of 8 -iso- $\mathrm{PGF}_{2 \alpha}$ were prepared in $50 \%$ $\mathrm{MeOH}$ with concentrations of $10,16,20,50,100$, 200 and $500 \mu \mathrm{g} / \mathrm{L}$ for the preparation of the calibration curve $(\mathrm{CC})$ samples, and with concentrations of $10,25,250$, and $400 \mu \mathrm{g} / \mathrm{L}$ for the preparation of the lower limit of quantification (LLOQ) and quality control (QC) samples at three levels.

\section{Preparation of calibration curve (CC) and quality} control (QC) samples

Plasma from young, healthy subjects who consented to participate in the study, immediately separated from blood cells at $4{ }^{\circ} \mathrm{C}$ after blood withdrawal and pooled promptly, was used for the preparation of CC and QC samples as follows: to $1980 \mu \mathrm{L}$ of plasma pool $20 \mu \mathrm{L}$, of the respective CC and LLOQ/QC, working solutions were added, mixed gently for 5 min, and frozen at $-20{ }^{\circ} \mathrm{C}, \mathrm{CC}$ concentrations being $0.10,0.16,0.20,0.50,1.0,2.0$ and $5.0 \mu \mathrm{g} / \mathrm{L}$; LLOQ/QCI - III levels - 0.1/0.25, 2.5 and $4.0 \mu \mathrm{g} / \mathrm{L}$.

\section{Sample preparation procedure}

In the development of the method, we employed a modified liquid-liquid extraction utilising phase separation. The procedure consists of eight consecutive steps: to a $15 \mathrm{~mL}$ sample tube, $500 \mu \mathrm{L}$ human plasma (CC, QC or patient-derived), and 100 $\mu \mathrm{L}$ of internal standard solution (IS) were added and gently mixed by vortex for $1 \mathrm{~min}$; further, $500 \mu \mathrm{L}$ of pre-saturated $\mathrm{NaH}_{2} \mathrm{PO}_{4}$ solution and $4.0 \mathrm{~mL}$ of ethyl ethanoate were added, and the sample was intensively mixed by vortex for $6 \mathrm{~min}$; after centrifugation for $10 \mathrm{~min}$ at $2500 \mathrm{~g}$, three distinct layers were obtained - upper organic and lower aqueous, which were separated by a layer of precipitated and salted out plasma proteins. The upper organic layer was transferred to another tube and evaporated under a gentle stream of nitrogen at $40{ }^{\circ} \mathrm{C}$. The dry residue was redissolved in $100 \mu \mathrm{L}$ of $\mathrm{MeOH}$-water $(1: 1 ; \mathrm{v} / \mathrm{v})$ and injected for analysis.

\section{Liquid chromatographic and mass spectrometric conditions}

The instrument consisted of Ultimate 3000 LC system equipped with a quaternary pump, an autosampler and a thermostat for chromatographic columns, and TSQ Quantum Access Max triple quadrupole mass spectrometer (Thermo Fisher Scientific, MA, USA). Chromatographic separation was performed under isocratic conditions on a coreshell Accucore ${ }^{\text {TM }}$ RP-MS $100 \times 2.1 \mathrm{~mm}, 2.6 \mu \mathrm{m}$ particles analytical column (Thermo Fisher Scientific, MA, USA), with a mobile phase consisting of $0.1 \%$ formic acid in $\mathrm{MeOH}$-water (65:35; v/v), flow rate $0.25 \mathrm{~mL} / \mathrm{min}$.

Heated electrospray ionisation (HESI) was used for analyte detection in negative ionisation mode with spray voltage $-4000 \mathrm{~V}$; source temperature $400{ }^{\circ} \mathrm{C}$; sheath gas, 45 arbitrary units; vaporiser temperature $280{ }^{\circ} \mathrm{C}$; capillary temperature $300^{\circ} \mathrm{C}$. Deprotonated molecules of analyte and IS were used as precursor ions for selected reaction monitoring (SRM) with transitions of $\mathrm{m} / \mathrm{z} 353.2 \rightarrow 193.1$ for 8-iso-PGF $2 \alpha$ and $357.2 \rightarrow 197.2$ for 8-iso-PGF $2 \alpha^{-d} 4$.

Argon was used as collision gas; collision energy was $28 \mathrm{~V}$. Calculation of concentrations was performed by the method of background subtraction.

\section{Method validation}

Selectivity was assessed with nine individual matrices of human plasma, including lipemic, hemolytic and icteric, applying the technique of standard additions at two concentration levels with predefined normalised matrix effect within 85-115\%. Imprecision and inaccuracy should also be in the range of $15 \%$ within and between runs for QC samples, and within $\pm 20 \%$ for the LLOQ sample; linearity in the defined CC range, with R2>0.996. Freezethaw stability should be verified for three cycles each lasting $24 \mathrm{~h}$, post-preparative stability for ten $\mathrm{h}$ at 4 ${ }^{\circ} \mathrm{C}$, short term stability of working solutions at room temperature for 72 hours at daylight and for 72 hours in the dark, stock solution stability and long term stability in plasma for over three months at $-20^{\circ} \mathrm{C}$; all of the above within $15 \%$ of theoretical. Validation experiments were designed according to current EMA/FDA industrial guidance for bioanalysis via LC-MS/MS (30, 31), encompassing four consecutive analytical runs, performed in four consecutive working days for the assessment of precision and accuracy, each with separate CC, with five replicates of the LLOQ and QC samples in the first day, and duplicate analysis of the LLOQ and QC samples in the next three days. A separate set of experiments was performed for validation of selectivity, matrix effect and stability of the method.

\section{Results and Discussion}

Although serum and plasma are considered similar, immediately separated plasma samples are typically used for eicosanoid and isoprostane measurements to avoid their oxidation and the clotting reaction in serum that leads to artificial in vitro increase of their concentrations. Protein molecules have different solubility in water, based on the amount 
and the type of amino acid residues on their surface. In aqueous solution, proteins have a coating of water molecules that stabilise them and prevent their aggregation. In our method for sample preparation, by employing the salting-out effect of saturated $\mathrm{NaH}_{2} \mathrm{PO}_{4}$, water envelope of plasma proteins is disturbed, and efficient protein precipitation takes place, which enhances extraction yield, purification and facilitates the separation of clear organic layer for further processing. However, in order to obtain complete precipitation of the proteins in a biological sample, it is necessary to fully saturate the solution, which can be achieved by using plenty of dry substance or appropriate volume of the pre-saturated solution of the given salt. In our sample pre-treatment procedure, pre-saturated $\mathrm{NaH}_{2} \mathrm{PO}_{4}$ was used to precipitate the proteins and ethyl ethanoate to extract both the analyte 8-iso-PGF $2 \alpha$ and IS 8-iso-PGF $2 \alpha-d 4$.

Figure 1 presents a picture of the sample after centrifugation with stable, thick and clearly visible protein precipitate separating the organic upper layer from the lower plasma water layer. Comparative experiment with the addition of an equal volume of water instead of the pre-saturated solution of $\mathrm{NaH}_{2} \mathrm{PO}_{4}$ showed 5 -fold lower recovery for both analytes (Table I).

The above sample pre-treatment is a modification of a more general procedure developed in our laboratories entitled phase separation protein precipitation, in which serum or plasma are treated with $\mathrm{MeOH}$, ethanol or acetonitrile, organic solvents fully miscible with water, in the presence of saturated salt solution. In this protein precipitation method, instead of obtaining two layers after centrifugation - supernatant as a mixture of plasma water and respective organic solvent, and precipitate on the bottom of the tube, three clearly separated layers are achieved as shown in Figure 1 - upper organic phase, protein precipitate in the middle, and lower plasma water phase. Thus, simplicity of protein precipitation is combined with extraction and purification - components of interest could be predominantly ether in the organic layer, or in the plasma water phase, both of which could be further used for analysis.

SRM chromatograms for the QC samples, obtained according to the described method are presented in Figure 2. Linearity was assured in the predefined range $0.1-5.0 \mu \mathrm{g} / \mathrm{L}$ with $\mathrm{R} 2=0.9998$ and

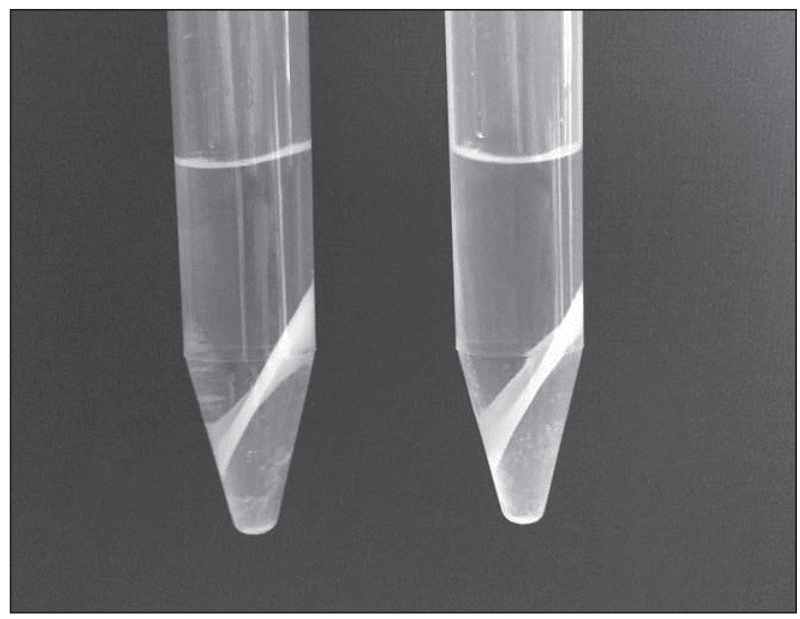

Figure 1 Sample tubes after centrifugation with clearly visible protein precipitate in the middle, separating the organic upper layer from the lower plasma water layer.

Table I Comparison between the recovery with and without saturated $\mathrm{NaH}_{2} \mathrm{PO}_{4}$.

\begin{tabular}{|l|c|c|}
\hline Sample name & $\begin{array}{c}\text { Recovery } \\
\text { 8-iso-PGF2a }\end{array}$ & $\begin{array}{c}\text { Recovery } \\
\text { 8-iso-PGF2a-d4 }\end{array}$ \\
\hline $\mathrm{H}_{2} \mathrm{O} \_$1* $^{*}$ & $9.60 \%$ & $8.80 \%$ \\
\hline $\mathrm{H}_{2} \mathrm{O}_{-} 2$ & $11.80 \%$ & $8.50 \%$ \\
\hline $\mathrm{s} \mathrm{NaH}{ }_{2} \mathrm{PO}_{4 \_} 1$ & $59.20 \%$ & $49.20 \%$ \\
\hline $\mathrm{s} \mathrm{NaH}{ }_{2} \mathrm{PO}_{4 \_} 2$ & $68.50 \%$ & $51.60 \%$ \\
\hline
\end{tabular}

* -1 and 2 for duplicate extractions; $\mathrm{H}_{2} \mathrm{O}$ - for using an equal volume of water instead of saturated (s) $\mathrm{NaH}_{2} \mathrm{PO}_{4}$

Table II Accuracy and precision of the assay.

\begin{tabular}{|c|c|c|c|c|c|c|}
\hline \multirow{3}{*}{ Level } & \multicolumn{4}{|c|}{ Accuracy (\% from theoretical) } & \multicolumn{2}{|c|}{ Precision (CV \%) } \\
\hline & \multicolumn{2}{|c|}{ within-run $(n=5)$} & \multicolumn{2}{|c|}{ between-run $(n=3)$} & \multirow{2}{*}{$\begin{array}{l}\text { within-run } \\
\qquad(n=5)\end{array}$} & \multirow{2}{*}{$\begin{array}{l}\text { between-run } \\
\qquad(n=3)\end{array}$} \\
\hline & $\min$ & $\max$ & $\min$ & $\max$ & & \\
\hline LLOQ (0.1mg/L) & $90.4 \%$ & $104.0 \%$ & $90.4 \%$ & $113.9 \%$ & $5.7 \%$ & $6.9 \%$ \\
\hline QC I (0.25 mg/L) & $91.4 \%$ & $105.2 \%$ & $87.6 \%$ & $105.2 \%$ & $5.6 \%$ & $6.2 \%$ \\
\hline QC II (2.5 mg/L) & $100.2 \%$ & $111.8 \%$ & $91.6 \%$ & $111.8 \%$ & $4.2 \%$ & $6.7 \%$ \\
\hline QC III (4.0 mg/L) & $105.1 \%$ & $109.4 \%$ & $94.8 \%$ & $109.4 \%$ & $1.5 \%$ & $5.4 \%$ \\
\hline
\end{tabular}




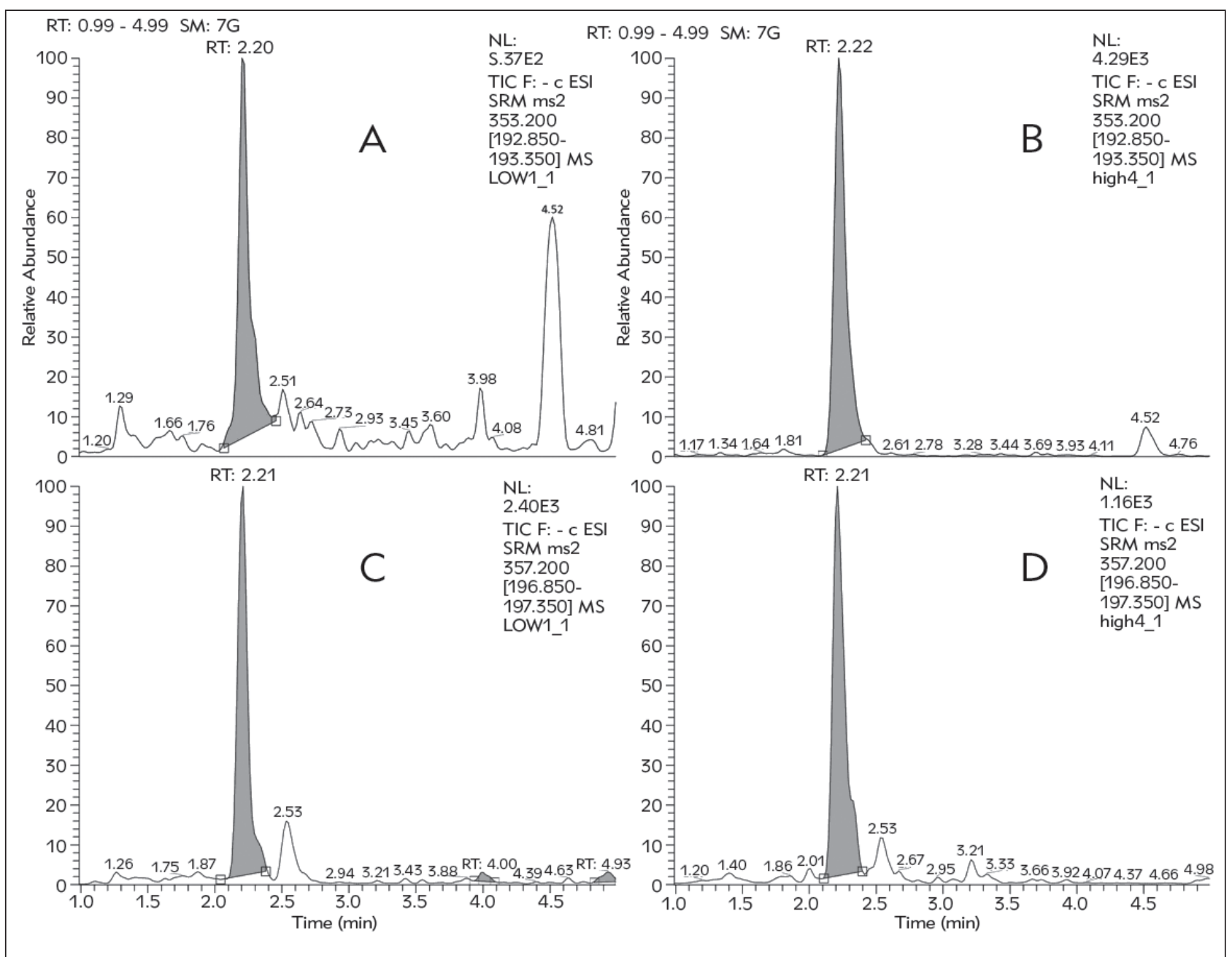

Figure 2 Chromatograms obtained from QC sample analysis. Concentrations of 8-iso-PGF2 $\alpha$ are: $0.25 \mu \mathrm{g} / \mathrm{L}(\mathrm{A})$ and $4.0 \mu \mathrm{g} / \mathrm{L}$ $(B)$, with the internal standard under each (C, D).

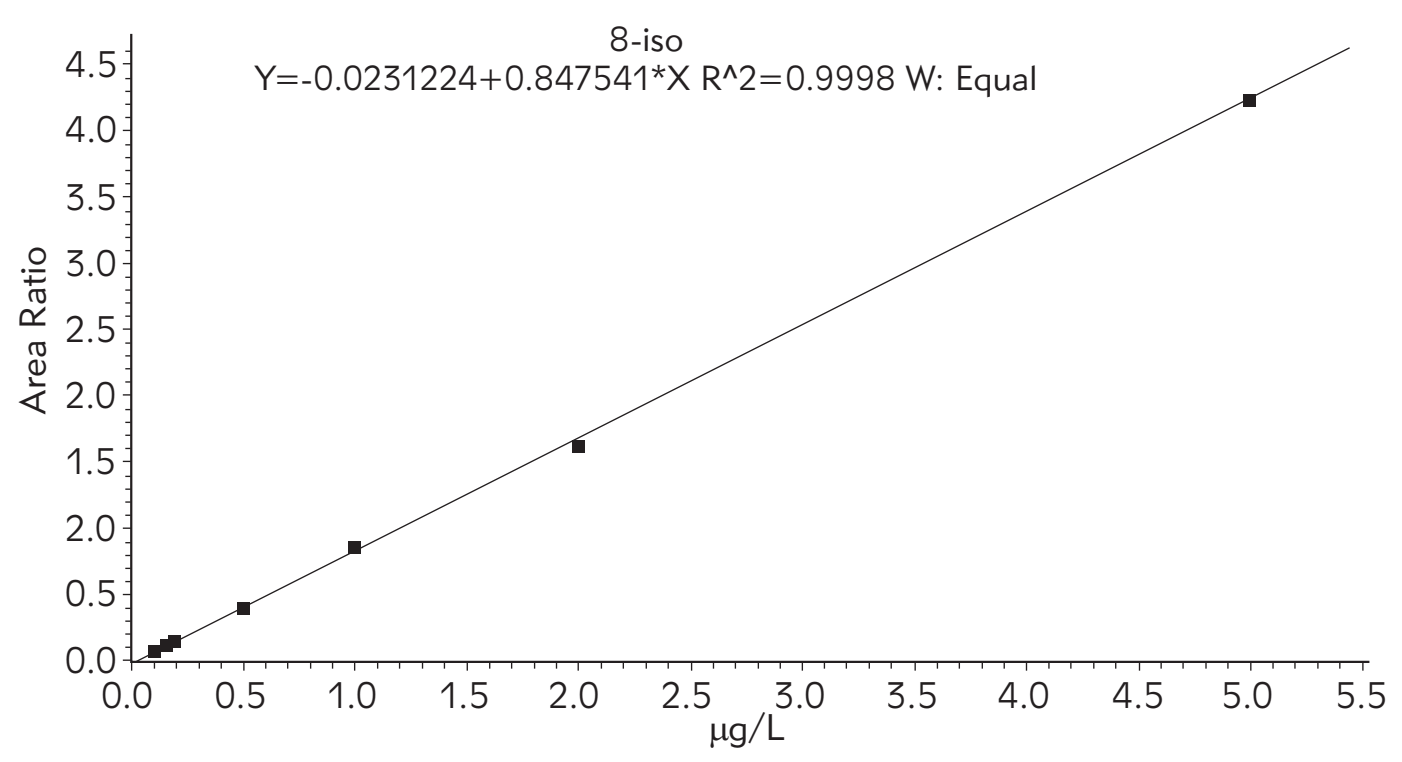

Figure 3 Calibration curve of 8 -iso-PGF $2 \alpha$. 
Table III Matrix effect of the assay, performed with 18 plasma matrices.

\begin{tabular}{|c|c|c|c|}
\hline Sample* & $\begin{array}{c}\text { Matrix effect } \\
\text { 8-isoPGF2a }\end{array}$ & $\begin{array}{c}\text { Matrix effect } \\
\text { 8-isoPGF2a-D4 }\end{array}$ & $\begin{array}{c}\text { Normalised } \\
\text { matrix effect }\end{array}$ \\
\hline VI_SA1 & $26.2 \%$ & $30.4 \%$ & $86.0 \%$ \\
\hline VI_SA2 & $51.7 \%$ & $53.0 \%$ & $97.5 \%$ \\
\hline VI_SA3 & $59.2 \%$ & $62.9 \%$ & $94.1 \%$ \\
\hline VI_SA4 & $62.9 \%$ & $60.9 \%$ & $103.2 \%$ \\
\hline VI_SA5 & $60.3 \%$ & $57.8 \%$ & $104.3 \%$ \\
\hline VI_SA6 & $59.1 \%$ & $56.0 \%$ & $105.5 \%$ \\
\hline VI_SA7 & $48.0 \%$ & $53.0 \%$ & $90.7 \%$ \\
\hline VI_SA8 & $45.0 \%$ & $48.4 \%$ & $93.1 \%$ \\
\hline VI_SA9 & $42.5 \%$ & $42.4 \%$ & $100.3 \%$ \\
\hline VI_SA10 & $38.7 \%$ & $40.9 \%$ & $94.7 \%$ \\
\hline VI_SA11 & $45.1 \%$ & $45.9 \%$ & $98.3 \%$ \\
\hline VI_SA12 & $43.6 \%$ & $43.5 \%$ & $100.2 \%$ \\
\hline \multirow{2}{*yyy}{} & min & min & min \\
\cline { 2 - 4 } & $26.2 \%$ & $30.4 \%$ & $86.0 \%$ \\
\hline max & max & max \\
\hline VI_SAB1 & $62.9 \%$ & $62.9 \%$ & $105.5 \%$ \\
\hline VI_SAB2 & $44.3 \%$ & $47.3 \%$ & $93.7 \%$ \\
\hline VI_SAH1 & $82.7 \%$ & $67.1 \%$ & $123.1 \%$ \\
\hline VI_SAH2 & $47.6 \%$ & $47.7 \%$ & $99.8 \%$ \\
\hline VI_SAL1 & $57.6 \%$ & $54.2 \%$ & $106.2 \%$ \\
\hline & $51.1 \%$ & $51.2 \%$ & $99.8 \%$ \\
\hline
\end{tabular}

*: VI SA1 - VI SA12: 12 individual plasma matrices, including 2 icteric (VI SABB1 and VI SAB2), 2 haemolytic (VI SAH1 and $\mathrm{VI}$ _SAH2) and 2 lipemic (VI-SAL1 and VI_SAL2) ones

excellent linear equation (Figure 3). Accuracy and precision calculated from the LLOQ and QC samples fully met the pre-defined acceptance criteria (Table II).

Normalised matrix effect was also fully acceptable, being in the range $86.0 \%-106.5 \%$, except for a single plasma sample with excessive haemolysis, where normalised matrix effect reached $123.1 \%$. It should be noted that significant ion suppression

\section{References}

1. Saeidnia S, Abdollahi M. Toxicological and pharmacological concerns on oxidative stress and related diseases. Toxicol Appl Pharmacol 2013; 273(3): 442-55.

2. Marrocco I, Altieri F, Peluso I. Measurement and Clinical Significance of Biomarkers of Oxidative Stress in Humans. Oxid Med Cell Longev 2017; 2017: 6501046.

3. Cipak Gasparovic A, Zarkovic N, Zarkovic K, Semen K, Kaminskyy D, Yelisyeyeva $\mathrm{O}$ et al. Biomarkers of oxidative and nitro-oxidative stress: conventional and novel approaches. Br J Pharmacol 2017; 174(12): 1771-83. found for the individual plasma samples was efficiently compensated by the stable isotope labelled internal standard (Table III).

Stability of working solutions estimated at room temperature and at $4-8{ }^{\circ} \mathrm{C}$, was between $-2 \%$ and $\pm 6.9 \%$, well within the pre-defined criteria. Freezethaw stability for three cycles of 24 hours each, was between $-1.9 \%$ and $+5.1 \%$, also within the predefined criteria.

Some limitations of our method include the observed ion suppression effect, which though is fully compensated by the use of stable isotope-labelled internal standard, and LLOQ at the commonly accepted cut-off limit for registration of free radical damage. We applied the above sample pre-treatment for analysis with a more sensitive instrument and achieved significantly better sensitivity (unpublished data).

\section{Conclusions}

This study presents an improved method for the determination of 8 -iso-PGF $2 \alpha$ by LC-MS/MS in human plasma utilising modified LLE with phase separation. The proposed procedure is easy to implement and assures higher extraction yield, clear separation of organic layer from the plasma water phase and protein precipitates, and better-purified product for instrumental analysis. HPLC separation was optimised with the use of a C18 core-shell column and triple quadrupole MS/MS analysis provided the required selectivity and specificity. With a run time of $10 \mathrm{~min}$, a throughput of over 50 samples per working day could be performed. The method was validated according to the current industrial requirements and allowed for the accurate and precise determination of 8 -iso-PGF $2 \alpha$ in human plasma at diagnostically significant concentration range.

\section{Conflict of interest statement}

The authors stated that they have no conflicts of interest regarding the publication of this article.

4. Comporti M, Signorini C, Arezzini B, Vecchio D, Monaco B, Gardi C. F2-isoprostanes are not just markers of oxidative stress. Free Radic Biol Med 2008; 44(3): 247-56.

5. Roberts $\sqcup$, Morrow JD. Measurement of F2-isoprostanes as an index of oxidative stress in vivo. Free Radic Biol Med 2000; 28(4): 505-13.

6. Milne GL, Sanchez SC, Musiek ES, Morrow JD. Quantification of F2-isoprostanes as a biomarker of oxidative stress. Nat Protoc 2007; 2(1): 221-6.

7. Catalá A. Lipid peroxidation of membrane phospholipids generates hydroxy-alkenals and oxidised phospholipids 
active in physiological and/or pathological conditions. Chem Phys Lipids 2009; 157(1): 1-11.

8. Niki E. Lipid peroxidation: physiological levels and dual biological effects. Free Radic Biol Med 2009; 47(5): 469-84.

9. Davies SS, Guo L. Lipid peroxidation generates biologically active phospholipids including oxidatively $\mathrm{N}$-modified phospholipids. Chem Phys Lipids 2014; 181: 1-33.

10. Morrow JD, Hill KE, Burk RF, Nammour TM, Badr KF, Roberts $\sqcup$. A series of prostaglandin F2-like compounds are produced in vivo in humans by a non- cyclooxygenase, free radical-catalysed mechanism. Proc Natl Acad Sci 1990; 87(23): 9383-7.

11. Morrow JD, Chen Y, Brame CJ, Yang J, Sanchez SC, Xu $J$, et al. The isoprostanes: unique prostaglandin-like products of free-radical-initiated lipid peroxidation. Drug Metab Rev 1999; 31(1): 117-39.

12. Dalle-Donne I, Rossi R, Colombo R, Giustarini D, Milzani A. Biomarkers of oxidative damage in human disease. Clin Chem 2006; 52(4): 601-23.

13. Giustarini D, Dalle-Donne I, Tsikas D, Rossi R. Oxidative stress and human diseases: Origin, link, measurement, mechanisms, and biomarkers. Crit Rev Clin Lab Sci 2009; 46(5-6): 241-81.

14. Galano JM, Mas E, Barden A, Mori TA, Signorini C, De Felice $C$ et al. Isoprostanes and neuroprostanes: total synthesis, biological activity and biomarkers of oxidative stress in humans. Prostaglandins Other Lipid Mediat 2013; 107: 95-102.

15. Basu S. F2-isoprostanes in human health and diseases: from molecular mechanisms to clinical implications. Antioxid Redox Signal 2008; 10(8): 1405-34.

16. Noble S, Neville D, Houghton R. Determination of 8-isoprostaglandin $\mathrm{F} 2 \alpha$ (8-iso- PGF $(2 \alpha)$ ) in human urine by ultra-performance liquid chromatography-tandem mass spectrometry. J Chromatogr B, Anal Technol Biomed Life Sci 2014; 947-948: 173-8.

17. Milne GL, Gao B, Terry ES, Zackert WE, Sanchez SC. Measurement of F2- isoprostanes and isofurans using gas chromatography-mass spectrometry. Free Radic Biol Med 2013; 59: 36-44.

18. Janicka M, Kubica P, Kot-Wasik A, Kot J, Namie nik J. Sensitive determination of isoprostanes in exhaled breath condensate samples with use of liquid chromatographytandem mass spectrometry. J Chromatogr B, Anal Technol Biomed Life Sci 2012; 893-894: 144-9.

19. Syslová K, Kacer P, Kuzma M, Klusácková P, Fenclová Z, Lebedová $J$ et al. Determination of 8-iso-prostaglandin $\mathrm{F}(2$ alpha) in exhaled breath condensate using combi- nation of immunoseparation and LC-ESI-MS/MS. J Chromatogr B, Anal Technol Biomed Life Sci 2008; 867(1): 8-14.

20. Milne GL, Dai Q, Roberts $\sqcup$ 2nd. The isoprostanes-25 years later. Biochim Biophys Acta 2015; 1851(4): 43345.

21. Chhonker YS, Bala V, Murry DJ. Quantification of eicosanoids and their metabolites in biological matrices: a review. Bioanalysis 2018; 10(24): 2027-46.

22. Dreissigacker U, Suchy MT, Maassen N, Tsikas D. Human plasma concentrations of malondialdehyde (MDA) and the F2-isoprostane 15(S)-8-iso-PGF(2alpha) maybe markedly compromised by hemolysis: evidence by GC-MS/MS and potential analytical and biological ramifications. Clin Biochem 2010; 43(1-2): 159-67.

23. Thakare R, Chhonker YS, Gautam N, Nelson A, Casaburi $\mathrm{R}$, Criner $\mathrm{G}$ et al. Simultaneous LC-MS/MS analysis of eicosanoids and related metabolites in human serum, sputum and BALF. Biomed Chromatogr 2018; 32(3).

24. Smith KA, Shepherd J, Wakil A, Kilpatrick ES. A comparison of methods for the measurement of 8-isoPGF $(2 \alpha)$ : a marker of oxidative stress. Ann Clin Biochem 2011; 48(Pt 2): 147-54.

25. Wiswedel I. F2-isoprostanes: sensitive biomarkers of oxidative stress in vitro and in vivo: a gas chromatography-mass spectrometric approach. Methods Mol Biol 2009; 580: 3-16.

26. Kortz L, Dorow J, Ceglarek U. Liquid chromatographytandem mass spectrometry for the analysis of eicosanoids and related lipids in human biological matrices: a review. J Chromatogr B, Anal Technol Biomed Life Sci 2014; 964: 1-11.

27. Tsikas D, Zoerner AA. Analysis of eicosanoids by LCMS/MS and GC-MS/MS: a historical retrospect and a discussion. J Chromatogr B, Anal Technol Biomed Life Sci 2014; 964: 79-88.

28. Puppolo M, Varma D, Jansen SA. A review of analytical methods for eicosanoids in brain tissue. J Chromatogr B, Anal Technol Biomed Life Sci 2014; 964: 50-64.

29. Willenberg I, Ostermann Al, Schebb NH. Targeted metabolomics of the arachidonic acid cascade: current state and challenges of LC-MS analysis of oxylipins. Anal Bioanal Chem 2015; 407(10): 2675-83.

30. European Medicines Agency. Guideline on bioanalytical method validation. EMEA/CHMP/EWP/192217/2009 2009. www.ema.europa.eu

31. USA FDA. Guidance for Industry: bioanalytical method validation. FDA-2013-D-1020 2018. www.fda.gov 